\title{
Taxonomic characterization of denitrifying bacteria that degrade aromatic compounds and description of Azoarcus toluvorans sp. nov. and Azoarcus toluclasticus sp. nov.
}

\author{
Bongkeun Song, ${ }^{1}$ Max M. Häggblom, ${ }^{1}$ Jizhong Zhou, ${ }^{2}$ James M. Tiedje ${ }^{3}$ \\ and Norberto J. Palleroni ${ }^{1}$
}

Author for correspondence: Norberto J. Palleroni. Tel: +1 7329329763 ext. 128. Fax: +1 7329328965 e-mail: palleroni@aesop.rutgers.edu

\footnotetext{
1 Biotechnology Center for Agriculture and the Environment, Cook College, Rutgers University, New Brunswick, NJ 08901-8520, USA

2 Environmental Sciences Division, Oak Ridge National Laboratory, Oak Ridge, TN 37831, USA

3 Center for Microbial Ecology, Michigan State University, East Lansing. MI 48824, USA
}

\begin{abstract}
A taxonomic characterization of twenty-one strains capable of degrading aromatic compounds under denitrifying conditions, isolated from ten different geographical locations, was performed on the basis of general morphological and physiological characteristics, cellular fatty acids, DNA base composition, small ribosomal (16S) subunit DNA sequences, whole-cell protein patterns and genomic DNA fragmentation analysis, in addition to DNA similarity estimations using hybridization methods. The collection of strains was subdivided into a number of different groups. A first group, consisting of four strains, could be assigned to the previously described species Azoarcus tolulyticus. A second group (five strains) had DNA which reannealed highly to that of strains of the first group, and it is considered to represent a genomovar of A. tolulyticus. The third and fourth groups, composed of a total of five strains, represent a new species of Azoarcus, Azoarcus toluclasticus (group 3) and a genomovar of this species (group 4), respectively. Finally, the fifth group, with two strains, corresponds to another new species of the genus Azoarcus, Azoarcus toluvorans. In addition to these five groups, the collection includes five individual strains perhaps representing as many different new species. The above classification is partially consistent with the results of approaches other than DNA-DNA hybridization (electrophoretic patterns of whole-cell proteins and of the fragments obtained after digestion of total DNA with infrequently cutting restriction enzymes). On the other hand, no correlation of these groupings was found in terms of the cellular fatty acid composition. It is also unfortunate that no simple sets of easily determinable phenotypic properties could be defined as being characteristic of each of the groups.
\end{abstract}

Keywords: Azoarcus toluvorans sp. nov., Azoarcus toluclasticus sp. nov., aromatic degradation, taxonomy

\section{INTRODUCTION}

In recent years many bacterial strains capable of growing at the expense of aromatic compounds under denitrifying conditions have been isolated from a variety of environments and subjected to studies on the metabolic pathways operating in the degradation of substrates (Altenschmidt \& Fuchs, 1991; Biegert \& Fuchs, 1996; Chee-Sanford et al., 1996; Frazer et al., 1995; Gorny et al., 1992; Heider \& Fuchs, 1997; Migaud et al., 1996). A number of these isolates have been assigned to the genera Azoarcus and Thauera (Anders et al., 1995; Fries et al., 1994; Rabus \& Widdel, 1996; Rhee et al., 1997; Seyfried et al., 1994; Springer et al., 1998; Zhou et al., 1995). Interestingly, although these two genera represent a major group of organisms of this type, the identification of the first Azoarcus species, Azoarcus indigens, was based on the capacity for dinitrogen fixation that it had as a member of the rhizosphere microflora of Kallar grass, which grows in arid regions of Pakistan (Reinhold-Hurek et al., 1993). A second species, Azoarcus communis, was 
identified for strains that shared the property of nitrogen fixation, but differed in morphological and physiological characteristics from the type species (Reinhold-Hurek et al., 1993). Additional strains with the basic properties of the genus Azoarcus and characterized by genomic fingerprinting criteria, were added to the genus (Hurek et al., 1997).

The property of denitrification was negative in the type species, $A$. indigens, but it was present in the strains later assigned to the same genus, which suggested a change in the generic definition (Anders et al., 1995). A denitrifying strain $\mathrm{KB} 740^{\mathrm{T}}$ was assigned to the genus under the new name Azoarcus evansii. Aside from being able to fix dinitrogen, this strain was able to degrade 2-aminobenzoate, 2-fluorobenzoate and $p$ cresol under denitrifying conditions (Anders et al., 1995). Eight strains degrading toluene under denitrifying conditions were assigned to the new species Azoarcus tolulyticus (Zhou et al., 1995). They are also able to grow in a medium free of combined nitrogen. Recently, a new species able to degrade resorcinol and grow under obligate denitrifying conditions has been described under the name Azoarcus anaerobius (Springer et al., 1998). Additional Azoarcus strains capable of degrading aromatic compounds or cyclic compounds under denitrifying conditions have been isolated, but have not been assigned to any of the known species (Harder, 1997; Rabus \& Widdel, 1996; Rhee et al., 1997; van Schie \& Young, 1998).

Strains degrading toluene under conditions of denitrification were assigned to the species Azoarcus tolulyticus on the basis of their 16S rRNA gene sequences and their fatty acid composition (Zhou et al., 1995). A large number of isolates obtained from an aquifer at Moffett Field, California, USA, were added to the collection on the basis of fatty acid profiles characteristic of Azoarcus (Fries et al., 1997a). Their properties included the degradation of toluene and phenol in combination with the capacity of co-metabolizing trichloroethylene. Lately, new strains isolated from aquifer sediments in Northern Michigan were reported as toluene degraders under denitrifying conditions. Their taxonomic position was not determined (CheeSanford et al., 1996).

In this paper, we report the results of polyphasic study of strains previously assigned to the species Azoarcus tolulyticus, together with recently isolated strains which are able to degrade toluene and phenol. The collection was found to include three species and, in addition, five strains not closely related to one another or to the other members of the collection, and which may perhaps be members of as many additional species.

\section{METHODS}

Organisms and growth conditions. A total of 21 denitrifying strains capable of degrading aromatic compounds was used for this study (Table 1). The strains were isolated using BS medium plus $5 \mathrm{mM} \mathrm{NO}-\mathrm{m}_{3}^{-}$plus toluene vapours or phenol and
Table 1. Geographical origins of strains and DNA G $+C$ content

\begin{tabular}{|c|c|c|}
\hline Strain & Geographical origin & $\begin{array}{c}G+C \\
(\mathrm{~mol} \%)\end{array}$ \\
\hline $2 \mathrm{a} 1$ & $\begin{array}{l}\text { Aquifer sediment, Wexford, } \\
\text { Northern Michigan, USA }\end{array}$ & $68 \cdot 1$ \\
\hline $3 a 1$ & $\begin{array}{l}\text { Aquifer sediment, Kalkaska, } \\
\text { Northern Michigan, USA }\end{array}$ & $67 \cdot 9$ \\
\hline $7 \mathrm{a} 1$ & $\begin{array}{l}\text { Aquifer sediment, Kalkaska, } \\
\text { Northern Michigan, USA }\end{array}$ & $68 \cdot 6$ \\
\hline BL2 & $\begin{array}{l}\text { Aquifer sediment, Bear Lake, } \\
\text { Northern Michigan, USA }\end{array}$ & $68 \cdot 2$ \\
\hline BL11 & $\begin{array}{l}\text { Aquifer sediment, Bear Lake, } \\
\text { Northern Michigan, USA }\end{array}$ & $67 \cdot 4$ \\
\hline MF7 & $\begin{array}{l}\text { Shallow aquifer sediment, Moffett } \\
\text { Field, California, USA }\end{array}$ & $67 \cdot 7$ \\
\hline MF23 & $\begin{array}{l}\text { Shallow aquifer sediment, Moffett } \\
\text { Field, California, USA }\end{array}$ & $67 \cdot 8$ \\
\hline MF58 & $\begin{array}{l}\text { Shallow aquifer sediment, Moffett } \\
\text { Field, California, USA }\end{array}$ & $66 \cdot 1$ \\
\hline MF62 & $\begin{array}{l}\text { Shallow aquifer sediment, Moffett } \\
\text { Field, California, USA }\end{array}$ & $61 \cdot 8$ \\
\hline $\mathrm{MF} 63^{\mathrm{T}}$ & $\begin{array}{l}\text { Shallow aquifer sediment, Moffett } \\
\text { Field, California, USA }\end{array}$ & $66 \cdot 8$ \\
\hline MF66 & $\begin{array}{l}\text { Shallow aquifer sediment, Moffett } \\
\text { Field, California, USA }\end{array}$ & $67 \cdot 6$ \\
\hline MF107 & $\begin{array}{l}\text { Shallow aquifer sediment, Moffett } \\
\text { Field, California, USA }\end{array}$ & $67 \cdot 4$ \\
\hline MF118 & $\begin{array}{l}\text { Shallow aquifer sediment, Moffett } \\
\text { Field, California, USA }\end{array}$ & $67 \cdot 8$ \\
\hline MF441 & $\begin{array}{l}\text { Shallow aquifer sediment, Moffett } \\
\text { Field, California, USA }\end{array}$ & $68 \cdot 0$ \\
\hline Tol-4 ${ }^{\mathrm{T}}$ & $\begin{array}{l}\text { Aquifer sediment, Bear Lake, } \\
\text { Northern Michigan, USA }\end{array}$ & $66 \cdot 9$ \\
\hline Td1 & $\begin{array}{l}\text { Soil from petroleum-contaminated } \\
\text { site, Washington, USA }\end{array}$ & $69 \cdot 3$ \\
\hline $\mathrm{Td} 2$ & $\begin{array}{l}\text { Soil from petroleum-contaminated } \\
\text { site, Washington, USA }\end{array}$ & $67 \cdot 8$ \\
\hline Td3 & $\begin{array}{l}\text { Marine sediment, Hunting Beach, } \\
\text { California, USA }\end{array}$ & $68 \cdot 5$ \\
\hline Td17 & $\begin{array}{l}\text { Soil from industrial area, } \\
\text { Jabaquara, Sao Paulo State, Brazil }\end{array}$ & $66 \cdot 9$ \\
\hline Td19 & $\begin{array}{l}\text { Soil from landfill, Cubatao, Sao } \\
\text { Paulo State, Brazil }\end{array}$ & $67 \cdot 3$ \\
\hline $\mathrm{Td} 21^{\mathrm{T}}$ & $\begin{array}{l}\text { Muck soil, Clinton County, } \\
\text { Michigan, USA }\end{array}$ & $68 \cdot 6$ \\
\hline
\end{tabular}

modified R2A (M-R2A) medium from various environments including agricultural soils, composts, aquifers and contaminated soils from different geographic regions (CheeSanford et al., 1996; Fries et al., 1994, 1997b). For the purpose of culturing these strains, M-R2A medium was used as described previously (Fries et al., 1994).

Morphology and physiological tests. Cell dimensions and morphology were determined by phase-contrast microscopy. Flagellation was determined using Leifson's method (Leifson, 1951). The presence of catalase and oxidase was tested as described by Smibert \& Kreig (1994). Growth on 
nutrient, brain-heart infusion and trypticase soy media was tested at $30^{\circ} \mathrm{C}$ under aerobic conditions. Growth on toluene was tested in the presence of nitrate and an anaerobic atmosphere with toluene as described previously (Evans et al., 1991). Growth on various substrates was determined at $30^{\circ} \mathrm{C}$ under aerobic and denitrifying conditions, using minimal salts medium plates (Tschech \& Fuchs, 1987) containing $1 \mathrm{mM}$ final concentration of acetate, benzoate, butyrate, caproate, fructose, fumarate, glucose, 2-hydroxybenzoate, 3-hydroxybenzoate, 4-hydroxybenzoate, 4hydroxyphenylacetate, phenol, phenylacetate, phthalate, propionate, pyruvate, succinate, valerate, D-xylose, Larabinose, D-ribose, D-galactose, sucrose, lactose, maltose, starch, adipate, tartrate, lactate, mannitol, aspartate, proline, phenylalanine, arginine, acetamide or histamine.

Determination of cellular fatty acids. All of the strains, including strains KB $740^{\mathrm{T}}$, $\mathrm{T} 1$ and $\mathrm{K} 172^{\mathrm{T}}$, were precultured under denitrifying conditions in minimal salts medium with $10 \mathrm{mM}$ succinate and $30 \mathrm{mM}$ nitrate (Tschech \& Fuchs, 1987). After the $\mathrm{OD}_{620}$ of the cultures reached 0.4 , the cells were used as an inoculum (10\%) for $50 \mathrm{ml}$ fresh liquid medium containing $10 \mathrm{mM}$ succinate and $30 \mathrm{mM}$ nitrate in anaerobic serum bottles and cultivated for $24 \mathrm{~h}$ at $30^{\circ} \mathrm{C}$ under an argon atmosphere. The cells were collected by centrifugation at room temperature. The fatty acids were saponified, methylated, extracted and analysed by GC using the SHERLOCK Microbial Identification System (MIDI). Identification was confirmed by GC-MS using a HP 5890 series II GC (Hewlett Packard) equipped with an HP 5971 mass selective detector and an HP5MS column ( $30 \mathrm{~m} \times 0.25 \mathrm{~mm}, 0.25 \mu \mathrm{m}$ film thickness; Hewlett Packard). Helium was used as the carrier gas. The injector was heated to $250^{\circ} \mathrm{C}$ with an initial column temperature of $60^{\circ} \mathrm{C}$ for $1 \mathrm{~min}$, increasing at the rate of $20^{\circ} \mathrm{C} \mathrm{min}{ }^{-1}$ to $300^{\circ} \mathrm{C}$.

Genomic bacterial DNA isolation. Chromosomal DNA of each strain was isolated as previously described (Song et al., 1998). The extracted DNA was sheared by two passages through a French press at 20000 p.s.i. (138 MPa) and diluted to $0.4 \mathrm{mg} \mathrm{DNA} \mathrm{ml}^{-1}$. The purity of the DNA was determined by measuring absorbance at 230, 260 and $280 \mathrm{~nm}$. The $A_{260} / A_{280}$ and $A_{260} / A_{230}$ ratios were in all cases close to 2 .

Measurement of $\mathbf{G}+\mathbf{C}$ content. The $\mathrm{G}+\mathrm{C}$ content of DNA was measured by HPLC following the method of Mesbah et al. (1989) with salmon sperm DNA as a standard. The nucleotides were analysed by HPLC (Beckman Instruments) with a reversed phase $\mathrm{C} 18$ column $(250 \times 4.6 \mathrm{~mm}$; Beckman Instruments) and a solvent of $12 \%$ HPLC-grade methanol and $20 \mathrm{mM}$ triethylamine at a flow rate of $1.5 \mathrm{ml} \mathrm{min}$. Absorbance was monitored at a wavelength of $254 \mathrm{~nm}$.

Determination and analysis of 165 rRNA gene sequence. The 16S rRNA gene was PCR amplified with the universal eubacterial primers fD1 and rP1 (Weisburg et al., 1991). The DNA sequences of the 16S rRNA genes were determined directly using the PCR-amplified DNA as the sequencing template. The amplified PCR products were purified using the Wizard PCR Preps DNA purification system (Promega) according to the manufacturer's instructions. DNA sequences were determined with automated fluorescent $\mathrm{Taq}$ cycle sequencing using the $\mathrm{ABI}$ Catalyst 800 and $\mathrm{ABI} 373 \mathrm{~A}$ Sequencer (Applied Biosystems). Approximately $100 \mathrm{ng}$ of the purified DNA was used for one automated fluorescent sequencing reaction. The primers for sequencing used in this study spanning the Escherichia coli 16S rRNA gene positions are fD1 (8-27), f270 (246-261), f519 (519-533), f788 (787-802), f1099 (1099-1144), r350 (357-342), r529 (529-512), r925 (920-906), r1240 (1242-1227) and rP1(1511-1492). Multiple sequence alignment was done with the PILEUP program in the Genetics Computer Group (GCG) software package (Devereux et al., 1984). The phylogenetic analyses were performed with the PHYLIP 3.5 program (Felsenstein, 1989). Kimura's method (Kimura, 1980) was used to calculate evolutionary distances, from which a phylogenetic dendrogram was drawn using neighbourjoining analysis (Saitou \& Nei, 1987). The SEQBOOT program was used to obtain confidence levels for neighbour-joining analysis using a 100 bootstrapped data set (Felsenstein, 1985).

DNA-DNA hybridization. The DNA preparations were labelled using the BRL nick-translation kit with ${ }^{3} \mathrm{H}$-radiolabelled dTTP. DNA-DNA hybridization was performed using the S1 nuclease method as reported in detail previously (Song et al., 1998).

DNA homology value transformation. The construction of a three-dimensional model for the DNA homology values was performed with the 3D program calculating a threedimensional coordinate using the DNA homology value (HOM) (Hildebrand et al., 1982). The accuracy, limitations and predictability of the program are reported elsewhere (Hildebrand et al., 1984).

PAGE of soluble cell proteins. After the cells were aerobically cultured for $1 \mathrm{~d}$ in M-R2A liquid medium at $30^{\circ} \mathrm{C}$, the protein sample was prepared as previously described by Jackman (1984). The amount of protein in the cell suspension was measured by heating the cells in $1 \mathrm{M} \mathrm{NaOH}$ for $10 \mathrm{~min}$ and assaying by the Bradford method (Bradford, 1976). SDS-PAGE $(10 \%)$ was performed by a slightly modified Laemmli method (Hood et al., 1988). Electropherograms were developed for $17 \mathrm{~h}$ in a Protean II xi vertical electrophoresis cell (Bio-Rad) at $10 \mathrm{~mA}$ and $20^{\circ} \mathrm{C}$. The protein banding pattern was revealed by staining with $0.2 \%$ Coomassie brilliant blue R-250 and $0.2 \%$ Coomassie brilliant blue G-250 in $50 \%(\mathrm{v} / \mathrm{v})$ methanol plus $15 \%$ acetic acid.

PFGE. PFGE analysis was performed using the method of Rainey et al. (1994). The embedded DNAs were treated with restriction endonuclease $X b a \mathrm{I}$ which yields between 20 and 30 DNA fragments. Not I and AspI were also tested, but they are not useful for genomic characterization, since they digested the chromosomal DNA into many small fragments. The digested DNA slivers were loaded on a $1.3 \%$ agarose gel and the gels were electrophoresed in a contour-clamped homogeneous electric field DR II PFGE system (Bio-Rad) at $200 \mathrm{~V}$ with a ramped pulse time of $1-25 \mathrm{~s}$ for $23 \mathrm{~h}$ at $14{ }^{\circ} \mathrm{C}$.

\section{RESULTS AND DISCUSSION}

\section{Morphological and physiological features}

The cells of $A$. tolulyticus strains were reported to be short motile rods (Zhou et al., 1995), and the same appears to be true for cells of the isolates from Moffett Field and Northern Michigan (Fig. 1). Motility is due to the presence of single polar flagella.

The biochemical properties of the isolates are very similar, with minor exceptions. All strains are oxidasepositive and the catalase reaction is positive, except for some strains from Moffett Field (MF7, MF23, MF58, MF62, MF63 ${ }^{\mathrm{T}}$, MF66 and MF441). Poor growth is observed on complex media such as nutrient, brainheart infusion and trypticase soy agar plates. Strain 

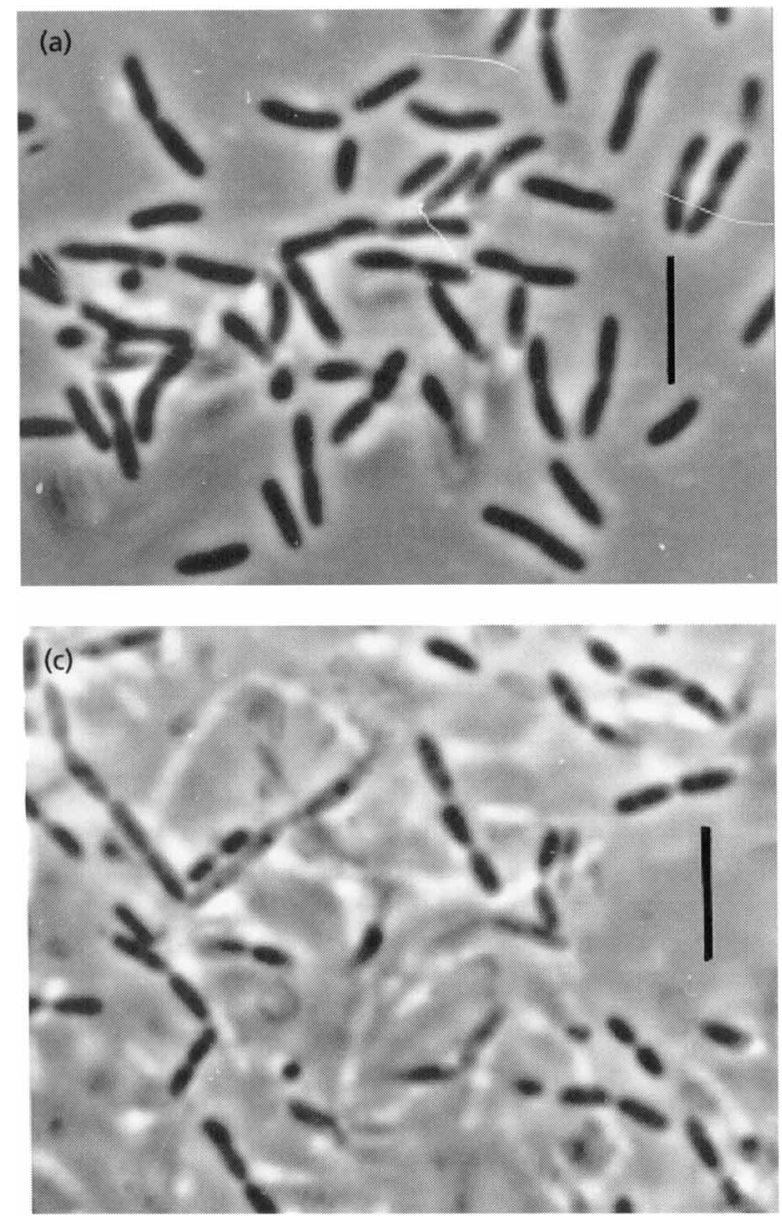
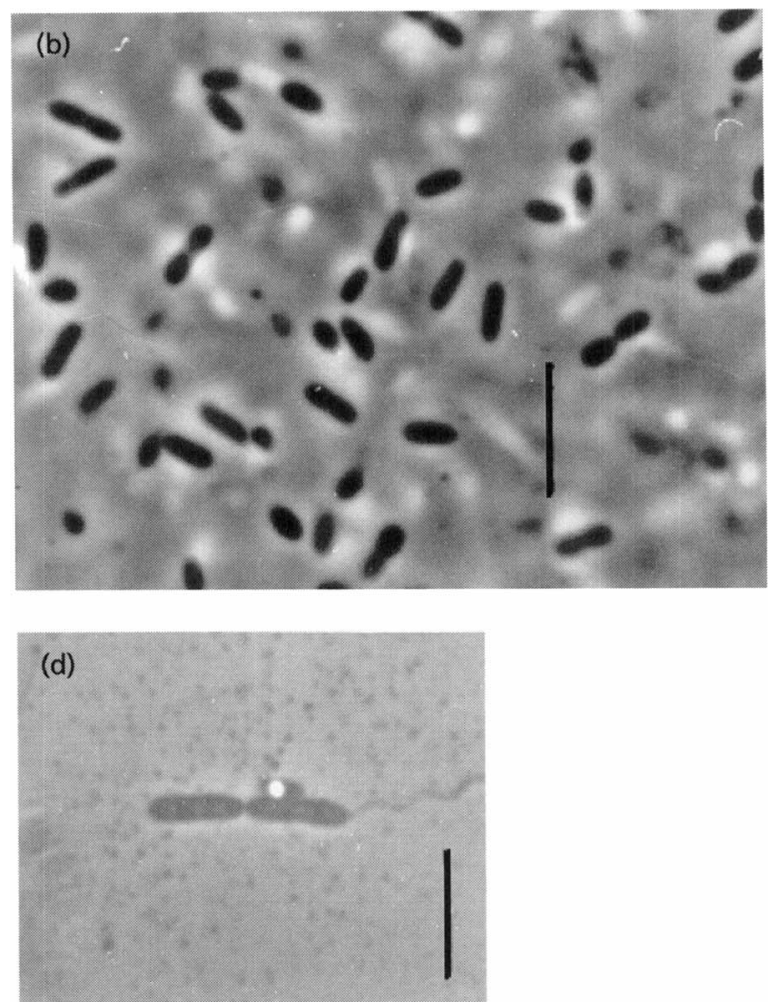

Fig. 1. Phase-contrast microscopic photographs of strains BL2 (a), MF23 (b) and MF58 (c). Leifson flagella stained preparation of strain MF7 (d). Strains were grown on nutrient plates for $48 \mathrm{~h}$. Bars, $5 \mu \mathrm{m}$.
MF62 does not grow on brain-heart infusion agar, strain $\mathrm{MF} 63^{\mathrm{T}}$ does not grow on nutrient agar and strain MF66 does not grow on nutrient or trypticase soy agar.

\section{$\mathbf{G}+\mathbf{C}$ content determination}

The members assigned to the species $A$. tolulyticus have a $\mathrm{G}+\mathrm{C}$ content of $66-69 \mathrm{~mol} \%$ (Table 1 ). This range is approximately the same for the isolates from Moffett Field (66-68 mol\%) and for the Northern Michigan strains (67-69 mol\%). Strain MF62 is exceptional in having a low $\mathrm{G}+\mathrm{C}$ content $(61 \cdot 8 \mathrm{~mol} \%)$. These results are compatible with the allocation of most strains to a single genus (Azoarcus). MF62 could be excluded because it differs by more than $5 \mathrm{~mol} \%$ in $\mathrm{G}+\mathrm{C}$ content from the other strains (Goodfellow \& O’Donnell, 1993).

\section{Cellular fatty acid analysis}

After culturing the cells as described in Methods, the predominant fatty acids of all strains were $12: 0,16: 0$,

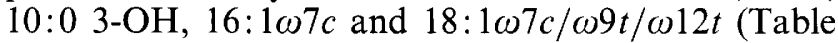
2 ). The identity of these fatty acids was confirmed by GC-MS (data not shown). Cluster analysis of the 21 strains (Fig. 2) showed that they were grouped at a
Euclidian distance of less than 9, with the exception of strain MF107, and that they could be differentiated into two groups at a Euclidian distance of 6, with the exception of the strains MF107 and MF62. On the basis of fatty acid analysis, strain MF107 could be located closer to the genus Thauera than to Azoarcus, considering the greater amount of $18: 1 \omega 7 c / \omega 9 t / \omega 12 t$ in its composition (Table 2).

Four main clusters were obtained within the Azoarcus group. Strains Tol-4 ${ }^{\mathrm{T}}$, Td1, Td2, Td19, 3a1, BL11 and MF66 grouped together at a Euclidian distance of less than 4. Several strains (MF23, MF58, MF63 ${ }^{\mathrm{T}}$, MF441, $2 \mathrm{a} 1,7 \mathrm{a} 1$ and $\mathrm{Td} 3$ ) were clustered together and were not differentiated further by fatty acid composition. Strains Td17, Td21 ${ }^{\mathrm{T}}$ and MF7 form a group at a Euclidian distance of less than 6. Strain MF118 was grouped with strain $\mathrm{KB} 740^{\mathrm{T}}$ (A. evansii). Thus, approximately 9 units of Euclidian distance could constitute the boundary for the differentiation between the genera Azoarcus and Thauera (Fig. 2).

\section{Phylogenetic analysis}

Strains of $A$. tolulyticus were previously studied for their taxonomic and phylogenetic relationships (Zhou et al., 1995). Partial sequencing studies of the 16S 
Table 2. Fatty acid composition of strains grown on succinate under denitrifying conditions

\begin{tabular}{|c|c|c|c|c|c|c|c|c|}
\hline \multirow[t]{2}{*}{ Strain } & \multicolumn{8}{|c|}{ Total fatty acids (\%) } \\
\hline & $10: 0$ & 10:0 3-ОН & $12: 0$ & $14: 0$ & $16: 1 \omega 7 c$ & $16: 1 \omega 5 c$ & $16: 0$ & $\begin{array}{c}18: 1 \omega 7 c / \\
\omega 9 t / \omega 12 t\end{array}$ \\
\hline Tol- $4^{\mathrm{T}}$ & $0 \cdot 6$ & $6 \cdot 6$ & $7 \cdot 1$ & 0.8 & $53 \cdot 7$ & $1 \cdot 0$ & $22 \cdot 1$ & $7 \cdot 8$ \\
\hline Td1 & 0.5 & 6.0 & $7 \cdot 0$ & $1 \cdot 0$ & $52 \cdot 8$ & $0 \cdot 4$ & $27 \cdot 5$ & $4 \cdot 8$ \\
\hline $\mathrm{Td} 2$ & $0 \cdot 7$ & $6 \cdot 2$ & $7 \cdot 0$ & $1 \cdot 0$ & $51 \cdot 2$ & $0 \cdot 0$ & $26 \cdot 8$ & $6 \cdot 7$ \\
\hline $\mathrm{Td} 3$ & $0 \cdot 5$ & $5 \cdot 6$ & $6 \cdot 2$ & $0 \cdot 7$ & $53 \cdot 2$ & $1 \cdot 0$ & $25 \cdot 7$ & $7 \cdot 2$ \\
\hline $\mathrm{Td} 17$ & $0 \cdot 4$ & $4 \cdot 3$ & $3 \cdot 7$ & $0 \cdot 5$ & $51 \cdot 2$ & $0 \cdot 9$ & $25 \cdot 8$ & 13.1 \\
\hline Td19 & 0.7 & $7 \cdot 2$ & $6 \cdot 8$ & $0 \cdot 7$ & $50 \cdot 6$ & $0 \cdot 8$ & $26 \cdot 2$ & $6 \cdot 8$ \\
\hline $\mathrm{Td} 21^{\mathrm{T}}$ & $0 \cdot 5$ & $3 \cdot 1$ & $4 \cdot 7$ & $0 \cdot 8$ & $51 \cdot 0$ & $0 \cdot 0$ & $29 \cdot 7$ & $10 \cdot 3$ \\
\hline MF7 & $0 \cdot 8$ & $4 \cdot 9$ & $6 \cdot 4$ & $0 \cdot 0$ & $53 \cdot 8$ & $0 \cdot 0$ & $23 \cdot 6$ & $10 \cdot 7$ \\
\hline MF23 & $0 \cdot 6$ & $3 \cdot 5$ & $6 \cdot 5$ & $0 \cdot 6$ & $53 \cdot 9$ & $0 \cdot 7$ & $25 \cdot 9$ & $7 \cdot 6$ \\
\hline MF58 & $0 \cdot 4$ & $5 \cdot 0$ & $5 \cdot 2$ & $0 \cdot 3$ & $53 \cdot 0$ & $0 \cdot 8$ & $26 \cdot 5$ & $8 \cdot 7$ \\
\hline MF62 & $0 \cdot 0$ & $3 \cdot 0$ & $4 \cdot 7$ & $3 \cdot 7$ & $56 \cdot 4$ & $0 \cdot 0$ & $28 \cdot 7$ & $2 \cdot 5$ \\
\hline MF63 & $0 \cdot 5$ & $5 \cdot 5$ & $5 \cdot 6$ & $0 \cdot 4$ & $51 \cdot 8$ & $0 \cdot 8$ & $25 \cdot 6$ & $9 \cdot 3$ \\
\hline MF66 & $0 \cdot 6$ & $6 \cdot 6$ & $7 \cdot 1$ & $1 \cdot 3$ & $52 \cdot 5$ & $0 \cdot 0$ & $26 \cdot 7$ & $5 \cdot 3$ \\
\hline MF 107 & 0.7 & $5 \cdot 7$ & $6 \cdot 3$ & 0.0 & $48 \cdot 5$ & $0 \cdot 0$ & $21 \cdot 7$ & 17.1 \\
\hline MF118 & 0.5 & $5 \cdot 7$ & $6 \cdot 5$ & 0.9 & $49 \cdot 3$ & $0 \cdot 0$ & $30 \cdot 9$ & 6.2 \\
\hline MF441 & $0 \cdot 5$ & $5 \cdot 6$ & $5 \cdot 7$ & $0 \cdot 3$ & $53 \cdot 1$ & $0 \cdot 9$ & $25 \cdot 5$ & 8.5 \\
\hline $2 \mathrm{a} 1$ & $0 \cdot 6$ & $6 \cdot 0$ & $6 \cdot 7$ & $0 \cdot 4$ & $52 \cdot 9$ & $0 \cdot 0$ & $26 \cdot 2$ & $7 \cdot 4$ \\
\hline $3 a 1$ & $0 \cdot 5$ & $6 \cdot 7$ & $6 \cdot 8$ & $0 \cdot 9$ & $50 \cdot 9$ & $0 \cdot 4$ & $27 \cdot 7$ & $5 \cdot 7$ \\
\hline $7 \mathrm{a} 1$ & $0 \cdot 5$ & $6 \cdot 1$ & $6 \cdot 4$ & $0 \cdot 5$ & 53.9 & 0.0 & $25 \cdot 7$ & $6 \cdot 9$ \\
\hline BL2 & $0 \cdot 5$ & $6 \cdot 7$ & $6 \cdot 5$ & $0 \cdot 4$ & $51 \cdot 2$ & $0 \cdot 6$ & $24 \cdot 0$ & $8 \cdot 6$ \\
\hline BL11 & $0 \cdot 5$ & $5 \cdot 5$ & $6 \cdot 3$ & 0.9 & $52 \cdot 2$ & 0.5 & $27 \cdot 1$ & $6 \cdot 5$ \\
\hline KB $740^{\mathrm{T}}$ & 0.8 & $8 \cdot 0$ & 6.9 & 0.8 & $46 \cdot 9$ & 0.5 & $27 \cdot 5$ & $8 \cdot 2$ \\
\hline
\end{tabular}

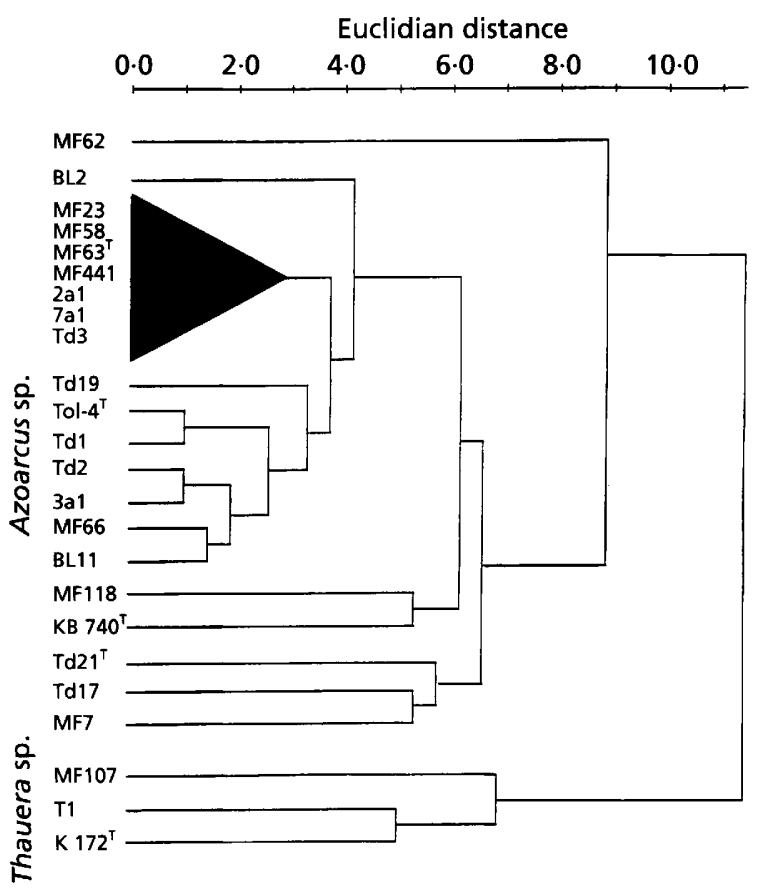

Fig. 2. Dendrogram of strains on the basis of cellular fatty acids analysis. Strains were grown with $10 \mathrm{mM}$ succinate and $30 \mathrm{mM}$ nitrate for $24 \mathrm{~h}$ under denitrifying conditions.
rRNA gene were performed on isolates from Moffett Field and Northern Michigan. From the preliminary analysis of the sequences, three strains (BL11, MF7 and $\mathrm{MF}^{\mathrm{T}}{ }^{\mathrm{T}}$ ) were selected for complete sequence analysis of the 16S rRNA gene. These strains share among them, and with strains Tol- $4^{\mathrm{T}}$ and $\mathrm{Td} 1$, over $99 \% 16 \mathrm{~S}$ rRNA sequence similarity (Table 3 ), and therefore are closely related to A. tolulyticus.

A neighbour-joining tree (Fig. 3) revealed that the species may be subdivided into three clusters. Thus, strains Tol- $4^{\mathrm{T}}$, Td1 and Td2 cluster with strain BL11, while two additional groups are evident $\left(\mathrm{Td} 17 / \mathrm{Td} 21^{\mathrm{T}}\right.$ and $\mathrm{Td} 3 / \mathrm{Td} 19)$. These last two groups appear to cluster in the neighbourhood of $A$. evansii (Fig. 3). Strains MF7 and MF63 ${ }^{\mathrm{T}}$ also clustered between the species $A$. tolulyticus and $A$. evansii.

The newly described species $A$. anaerobius (Springer $e t$ al., 1998) does not cluster with the strains included in our study, and it appears to be located outside of the cluster of $A$. tolulyticus and $A$. evansii, in agreement with basic differences in its physiological properties (Fig. 3). In view of the limitations of 16S rRNA sequence studies for the circumscription of taxa at the species level (Stackebrandt \& Goebel, 1994), it appears that a revision of the classification of Azoarcus species may be required in the near future. 
Table 3. Similarity (\%) and genetic distance of strains on the basis of 16S rRNA sequence analysis

Strains: 1, A. tolulyticus Tol-4 ${ }^{\mathrm{T}} ; 2$, A. tolulyticus Td1; 3, A. tolulyticus Td2; 4, Td3; 5, Td17; 6, Td19; 7, Td21 $; 8$, BL11;9, MF7; 10, MF63 ${ }^{\mathrm{T}} ; 11$, A. evansii KB $740^{\mathrm{T}} ; 12$, A . anaerobius LuFRes ${ }^{\mathrm{T}} ; 13$, A. indigens $\mathrm{VB} 32^{\mathrm{T}} ; 14, T$. aromatica $\mathrm{K} 172^{\mathrm{T}} ; 15$, $T$. aromatica $\mathrm{T} 1 ; 16, T$. selenatis $\mathrm{AX}^{\mathrm{T}}$. Top right, similarity; bottom left, genetic distance.

\begin{tabular}{|c|c|c|c|c|c|c|c|c|c|c|c|c|c|c|c|c|}
\hline Strain & 1 & 2 & 3 & 4 & 5 & 6 & 7 & 8 & 9 & 10 & 11 & 12 & 13 & 14 & 15 & 16 \\
\hline 1 & & $99 \cdot 8$ & $99 \cdot 3$ & $98 \cdot 2$ & $98 \cdot 3$ & $97 \cdot 7$ & $98 \cdot 1$ & $99 \cdot 5$ & $99 \cdot 3$ & 99.4 & $98 \cdot 6$ & $97 \cdot 1$ & $95 \cdot 0$ & $93 \cdot 1$ & $93 \cdot 3$ & $93 \cdot 4$ \\
\hline 2 & 0.07 & & $99 \cdot 3$ & $98 \cdot 2$ & $98 \cdot 3$ & $97 \cdot 7$ & $98 \cdot 1$ & $99 \cdot 5$ & $99 \cdot 3$ & $99 \cdot 4$ & $98 \cdot 6$ & $97 \cdot 1$ & $95 \cdot 0$ & $93 \cdot 1$ & $93 \cdot 3$ & 93.4 \\
\hline 3 & 0.37 & 0.30 & & $97 \cdot 9$ & $97 \cdot 8$ & $97 \cdot 3$ & $97 \cdot 7$ & $99 \cdot 0$ & $98 \cdot 8$ & 98.9 & $98 \cdot 1$ & $96 \cdot 8$ & $94 \cdot 4$ & $92 \cdot 5$ & $92 \cdot 7$ & $92 \cdot 8$ \\
\hline 4 & 1.82 & 1.74 & 1.82 & & $98 \cdot 5$ & 98.8 & 98.9 & $97 \cdot 9$ & $97 \cdot 9$ & $98 \cdot 0$ & $99 \cdot 2$ & $96 \cdot 6$ & $94 \cdot 8$ & $93 \cdot 0$ & $93 \cdot 2$ & 93.6 \\
\hline 5 & 1.66 & 1.59 & 1.89 & $1 \cdot 51$ & & $98 \cdot 2$ & $99 \cdot 1$ & $98 \cdot 0$ & $98 \cdot 3$ & $98 \cdot 3$ & $99 \cdot 2$ & $96 \cdot 6$ & $94 \cdot 5$ & $93 \cdot 5$ & $93 \cdot 7$ & $93 \cdot 3$ \\
\hline 6 & 2.05 & 1.97 & $2 \cdot 20$ & 0.98 & 1.59 & & 98.5 & $97 \cdot 4$ & 97.4 & $97 \cdot 5$ & 98.9 & $96 \cdot 1$ & $94 \cdot 2$ & $92 \cdot 3$ & $92 \cdot 4$ & $92 \cdot 7$ \\
\hline 7 & 1.89 & $1 \cdot 82$ & 1.97 & $1 \cdot 21$ & 0.90 & $1 \cdot 28$ & & $97 \cdot 8$ & $97 \cdot 9$ & $98 \cdot 0$ & $99 \cdot 3$ & $96 \cdot 3$ & $94 \cdot 3$ & $93 \cdot 1$ & $93 \cdot 3$ & $93 \cdot 2$ \\
\hline 8 & 0.45 & $0 \cdot 37$ & 0.68 & $2 \cdot 12$ & 1.97 & $2 \cdot 35$ & $2 \cdot 20$ & & $99-2$ & $99 \cdot 1$ & $98 \cdot 3$ & $96 \cdot 4$ & $94 \cdot 6$ & $92 \cdot 8$ & $93 \cdot 0$ & $93 \cdot 1$ \\
\hline 9 & 0.68 & $0 \cdot 60$ & 0.90 & $2 \cdot 12$ & 1.66 & $2 \cdot 35$ & $2 \cdot 12$ & $0 \cdot 83$ & & $99 \cdot 3$ & $98 \cdot 5$ & $97 \cdot 4$ & $94 \cdot 4$ & $93 \cdot 1$ & $93 \cdot 3$ & $93 \cdot 2$ \\
\hline 10 & 0.60 & 0.53 & 0.83 & 1.97 & 1.66 & $2 \cdot 20$ & 1.97 & 0.90 & 0.68 & & $98 \cdot 5$ & $97 \cdot 1$ & $94 \cdot 7$ & 93.0 & $93 \cdot 2$ & 93.4 \\
\hline 11 & 1.36 & $1 \cdot 28$ & $1 \cdot 59$ & 0.75 & 0.75 & $0 \cdot 83$ & 0.68 & 1.66 & $1 \cdot 51$ & $1 \cdot 51$ & & $96 \cdot 5$ & 94.9 & $93 \cdot 5$ & 93.6 & 93.7 \\
\hline 12 & $3 \cdot 21$ & $3 \cdot 13$ & $3 \cdot 44$ & $3 \cdot 76$ & 3.68 & $4 \cdot 23$ & $4 \cdot 15$ & $3 \cdot 52$ & $2 \cdot 82$ & $3 \cdot 13$ & $3 \cdot 68$ & & $95 \cdot 1$ & $94 \cdot 3$ & $94 \cdot 4$ & 93.8 \\
\hline 13 & 4.95 & $4 \cdot 87$ & $5 \cdot 19$ & $5 \cdot 11$ & $5 \cdot 35$ & $5 \cdot 43$ & $5 \cdot 60$ & $5 \cdot 27$ & $5 \cdot 52$ & $5 \cdot 19$ & 5.03 & $5 \cdot 60$ & & $94 \cdot 0$ & $94 \cdot 1$ & 942 \\
\hline 14 & $6 \cdot 81$ & 6.73 & $7 \cdot 05$ & 6.90 & $6 \cdot 40$ & $7 \cdot 39$ & 6.82 & $7 \cdot 14$ & $6 \cdot 81$ & 6.89 & $6 \cdot 48$ & 6.65 & 5.91 & & 99.8 & $97 \cdot 7$ \\
\hline 15 & $6 \cdot 65$ & 6.56 & 6.89 & $6 \cdot 73$ & $6 \cdot 24$ & $7 \cdot 22$ & 6.66 & 6.98 & 6.64 & $6 \cdot 73$ & $6 \cdot 32$ & 6.49 & $5 \cdot 75$ & 0.15 & & 97.8 \\
\hline 16 & 6.58 & 6.49 & $6 \cdot 82$ & $6 \cdot 25$ & 6.66 & 6.91 & $6 \cdot 83$ & 6.91 & $6 \cdot 82$ & 6.58 & $6 \cdot 33$ & $6 \cdot 34$ & $5 \cdot 76$ & $2 \cdot 36$ & $2 \cdot 20$ & \\
\hline
\end{tabular}

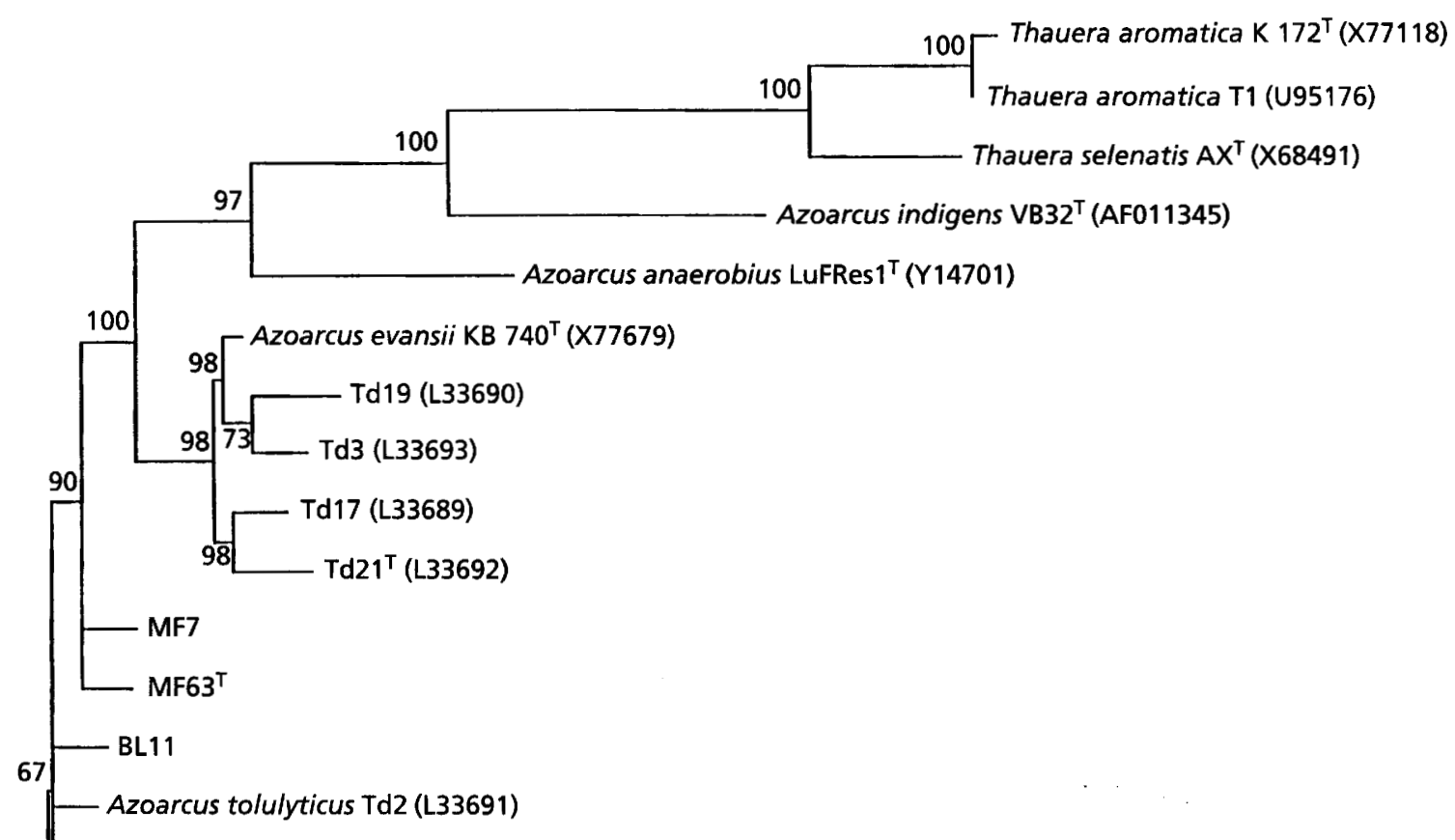

Fig. 3. Phylogenetic relationship of aromaticdegrading denitrifying strains BL11, MF7 and MF63 ${ }^{\top}$ belonging to the genera Azoarcus and Thauera of the beta subclass of Proteobacteria. Scale bar, 5 nucleotide substitutions in 100 bases.

\section{DNA-DNA hybridization experiments}

As shown in Fig. 4, the strains can be divided into five DNA homology groups. Strain Td1 has about $90 \%$ DNA similarity with $\mathrm{Td} 2$ and $\mathrm{Tol}-4^{\mathrm{T}}$, which were previously assigned to $A$. tolulyticus (Zhou et al., 1995), and the similarity of MF66 to Td 1 is $92 \%$, all of which indicates that these four strains (group 1) should be considered as belonging to the same species. On the other hand, strains Td3, Td17, Td19 and Td $21^{\mathbf{T}}$ have 


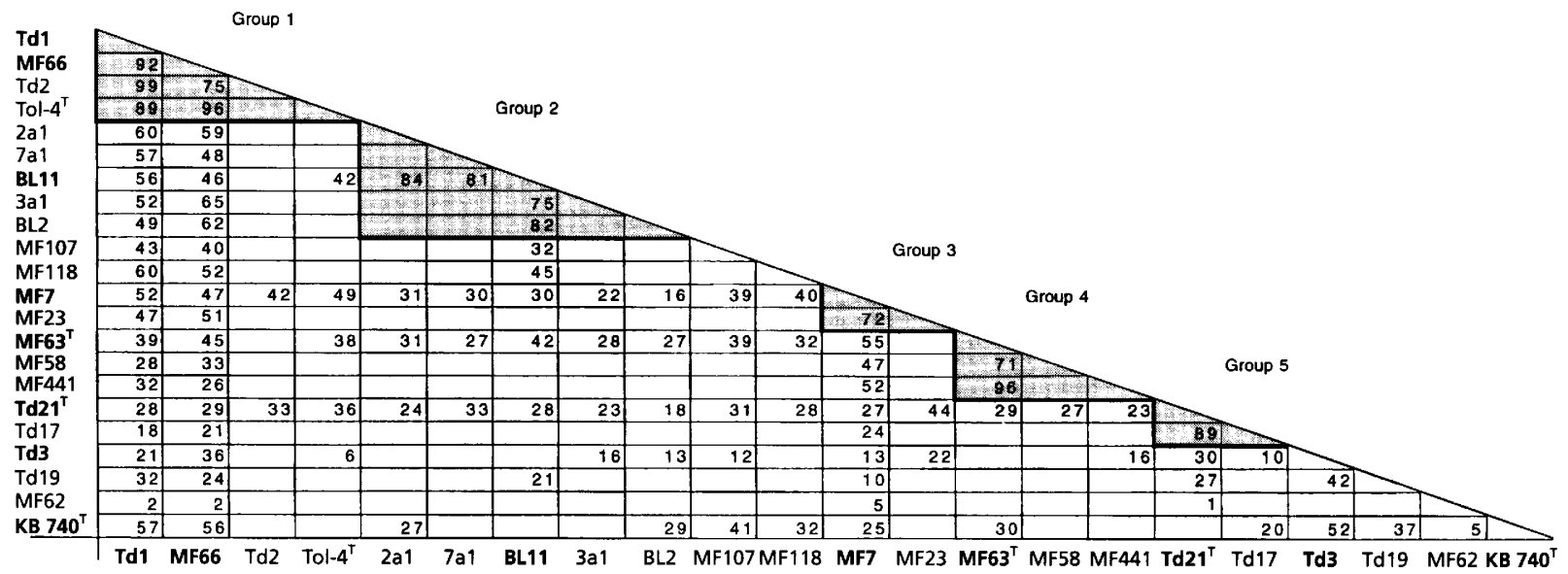

Fig. 4. Triangle matrix representation of pairwise DNA homology values. The heavy line and shaded regions indicate the strains within each one of the groups. Strains used as references in the DNA-DNA hybridization experiments are shown in bold.

less than $30 \%$ similarity with strain Td1. Of these four strains, strain $\mathrm{Td} 21^{\mathrm{T}}$ has $89 \%$ similarity with strain Td17, and therefore the two are considered to be members of another DNA homology group (group 5), whereas strains Td3 and Td19 have DNA of low similarity (about $30 \%$ ) with that of strain $\mathrm{Td} 21^{\mathrm{T}}$, and strain $\mathrm{Td} 3$ has $42 \%$ similarity with strain $\mathrm{Td} 19$, although these two strains form a cluster in the $16 \mathrm{~S}$ rRNA phylogenetic tree (Fig. 3).

Among strains from Moffett Field, strains MF7, $M F 63^{\mathrm{T}}$ and MF66 were chosen as reference strains. As shown in Fig. 4, strain MF7 has $72 \%$ DNA similarity with strain MF23 (not represented in Fig. 3), thus generating a new species group (group 3 ). This group has about $45 \%$ DNA similarity with the members of group 1 and with some Moffett Field isolates (strains MF58, MF63 ${ }^{\mathrm{T}}$, MF107, MF118 and MF441). On the other hand, 16S rRNA studies have shown the relatedness of strains MF7 and $M F 63^{\mathrm{T}}$; the latter has, in addition, 71 and $96 \%$ DNA similarity with strains MF58 and MF441, respectively, all of which indicates that strains MF63 ${ }^{\mathrm{T}}$, MF58 and MF441 constitute a new DNA homology group, which is named here as group 4.

Of strains from Northern Michigan, strain BL11, used as a reference strain, has more than $70 \%$ DNA similarity with the five isolates from the same origin (Table 1) and they are considered to constitute a new group, group 2. Members of this group have a mean DNA similarity of about $55 \%$ with strains of group 1 and about $30 \%$ with groups 3,4 and 5 , which is in agreement with the data of $16 \mathrm{~S}$ rRNA sequence analysis.

In summary, five groups are revealed in the collection under study on the basis of the DNA-DNA hybridization experiments (Fig. 4). The remaining strains (Td3, Td19, MF62, MF107 and MF118) have insig-

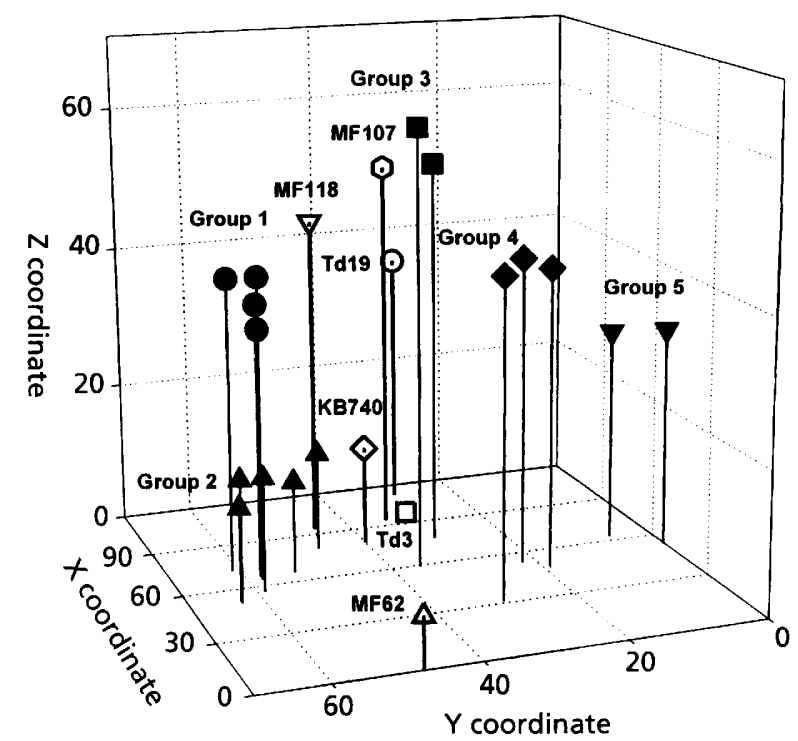

Fig. 5. Three-dimensional representation of species division of the genus Azoarcus based on DNA homology values.

nificant DNA similarity values among each other and with strains of the species groups defined in our work and they seem to represent separate taxa whose circumscription is better attempted when more strains are added to the collection.

\section{Three-dimensional models}

This representation, based on the results of DNADNA hybridization experiments, locates the various groups in a three-dimensional space (Fig. 5). The advantage of such a model is to emphasize the spatial relationships more clearly than the conventional bi- 


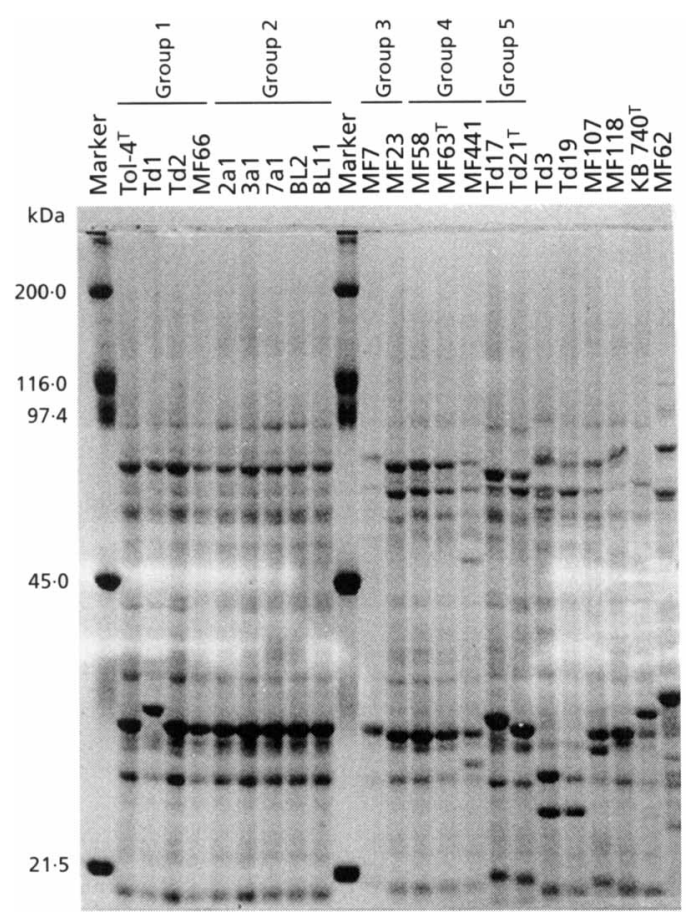

Fig. 6. Protein fingerprinting patterns of strains included in this study. Molecular masses of the marker proteins are indicated on the left-hand side.

dimensional dendrograms and to serve as a guide for future experiments to attain a further degree of refinement.

As can be seen in Fig. 5, the strains constituting groups 1 through 5 appear to form a large cluster on the basis of their DNA similarities, while one of the strains that could not be assigned to any group (strain MF62) is located far from the main cluster. The independent strains Td3, Td19, MF107, MF118 and KB $740^{\mathrm{T}}$ are found scattered within the main cluster.

\section{Comparison of protein electropherograms}

The protein profiles of the aromatic-compound-degrading denitrifiers were also examined (Fig. 6). Strains of group 1 (Tol-4 ${ }^{\mathrm{T}}, \mathrm{Td} 2$ and MF66) have very similar protein patterns except for strain Td1. Strains of group 2 (2a1, 3a1, 7a1, BL2 and BL11) have identical protein patterns and very similar profiles to those of group 1 . Strains of group 3 and group 4 (MF23, MF58 and $\mathrm{MF}^{\mathrm{T}}{ }^{\mathrm{T}}$ ) have similar protein patterns except for strains MF7 and MF441. Identical protein patterns are observed for the strains of the group 5 with the exception of one band. The remaining strains not included in any groups have a variety of protein patterns.

\section{DNA fragmentation analysis}

Visual evaluation of DNA fragmentation (Fig. 7) showed that strains in groups 1 and 3 have somewhat different DNA fragmentation patterns within their groups, whereas the strains in groups 2 and 4 have identical patterns within their groups. Strain Tol- ${ }^{\mathrm{T}}$ in group 1 has identical patterns of DNA fragmentation with the strains in group 2. Groups 3 and 4 have very different patterns although they share $45 \%$ DNA similarity. Each of the remaining strains (Td3, Td19, MF62, MF107 and MF118) has a distinctive DNA fragment pattern.

\section{Growth substrates}

Growth on various carbon substrates was tested under aerobic and denitrifying conditions. All the strains can grow both under aerobic and denitrifying conditions

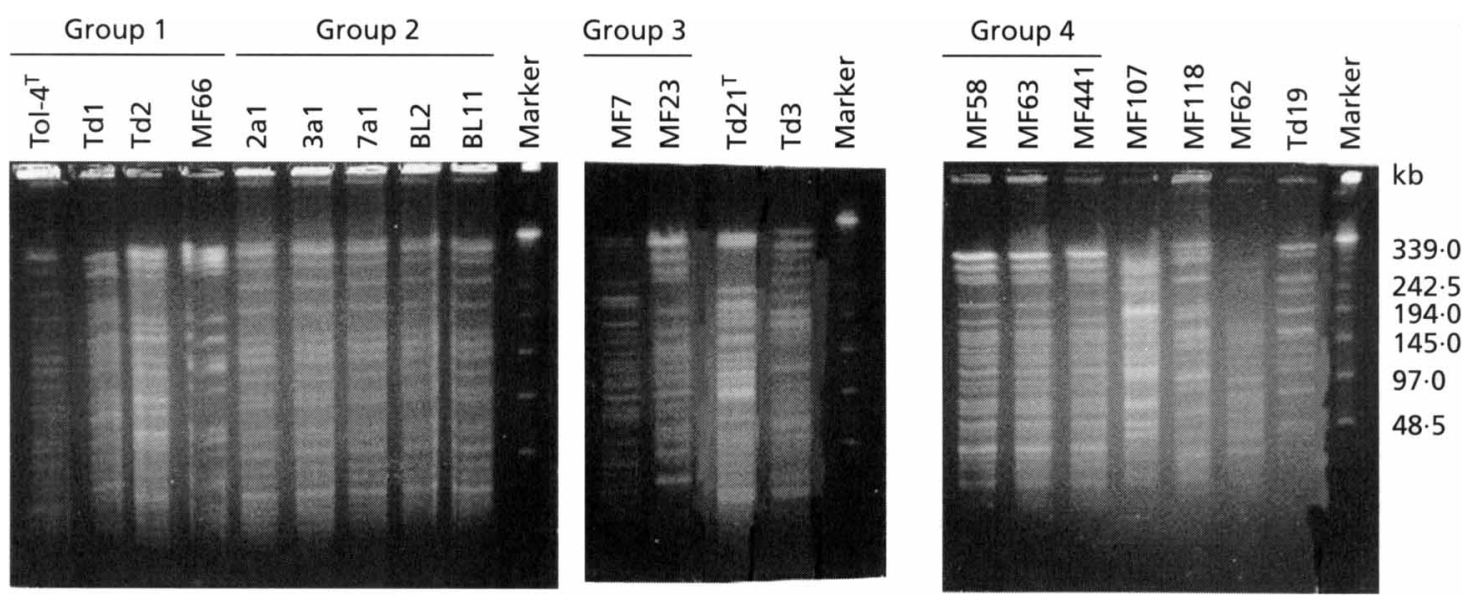

Fig. 7. Fragment separation of $X b a l$ digests of chromosomes from aromatic-compound-degrading denitrifying bacteria using contour-clamped homogeneous electric field gel electrophoresis with a ramped pulse time of $1-25 \mathrm{~s}$ for $23 \mathrm{~h}(1.3 \%$ agarose). 
Table 4. Growth of strains belonging to the species groups on various carbon sources under aerobic and denitrifying conditions

+ , Good growth; \pm , moderate growth; - , no growth; ND, not determined.

\begin{tabular}{|c|c|c|c|c|c|c|c|c|c|c|c|c|c|c|c|c|c|c|}
\hline & \multicolumn{8}{|c|}{ Group 1} & \multicolumn{10}{|c|}{ Group 2} \\
\hline & \multicolumn{2}{|c|}{ Tol-4 ${ }^{\mathrm{T}}$} & \multicolumn{2}{|c|}{ Td1 } & \multicolumn{2}{|c|}{ Td2 } & \multicolumn{2}{|c|}{ MF66 } & \multicolumn{2}{|c|}{ 2a1 } & \multicolumn{2}{|c|}{ 3a1 } & \multicolumn{2}{|c|}{$7 \mathrm{a} 1$} & \multicolumn{2}{|c|}{ BL2 } & \multicolumn{2}{|c|}{ BL11 } \\
\hline & $\mathrm{O}_{2}$ & $\mathrm{NO}_{3}^{-}$ & $\mathbf{O}_{2}$ & $\mathrm{NO}_{3}^{-}$ & $\mathrm{O}_{2}$ & $\mathrm{NO}_{3}^{-}$ & $\mathbf{O}_{2}$ & $\mathrm{NO}_{3}^{-}$ & $\mathbf{O}_{2}$ & $\mathrm{NO}_{3}^{-}$ & $\mathrm{O}_{2}$ & $\mathrm{NO}_{3}^{-}$ & $\mathbf{O}_{2}$ & $\mathrm{NO}_{3}^{-}$ & $\mathbf{O}_{2}$ & $\mathbf{N O}_{3}^{-}$ & $\mathrm{O}_{2}$ & $\mathrm{NO}_{3}^{-}$ \\
\hline Caproate & - & + & + & + & - & - & - & - & + & + & - & + & + & - & + & + & + & + \\
\hline D-Fructose & - & + & + & + & - & - & + & + & + & + & + & + & + & + & + & + & + & + \\
\hline Fumarate & - & & + & + & + & + & + & + & + & + & + & + & + & + & + & + & + & + \\
\hline D-Glucose & -1 & -+ & + & + & + & + & + & + & + & + & + & + & + & + & + & + & + & \pm \\
\hline 3-Hydroxybenzoate & $t$ & + & - & + & - & - & - & - & + & + & + & + & - & - & - & - & - & - \\
\hline 4-Hydroxyphenylacetate & -1 & + & + & + & - & - & - & - & + & + & + & + & - & - & - & - & - & - \\
\hline Phenol & $\mathrm{N}$ & \pm & ND & \pm & $\mathrm{ND}$ & \pm & + & + & ND & \pm & ND & \pm & ND & \pm & ND & - & ND & + \\
\hline Phenylacetate & + & + & + & + & - & - & - & - & + & + & + & + & - & - & + & + & + & + \\
\hline Propionate & 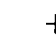 & + & - & + & - & - & - & - & + & - & - & - & - & - & + & + & - & - \\
\hline Toluene & t & + & + & + & + & + & + & + & + & + & + & + & + & + & + & + & + & + \\
\hline Valerate & - & - & + & + & - & + & - & - & + & + & - & + & + & + & - & + & + & - \\
\hline Lactose & -1 & + & + & + & + & + & + & + & + & + & + & + & + & + & + & + & + & + \\
\hline \multirow[t]{4}{*}{ Phenylalanine } & - & - & + & + & + & + & + & + & + & + & + & + & + & + & + & + & - & - \\
\hline & \multicolumn{4}{|c|}{ Group 3} & \multicolumn{6}{|c|}{ Group 4} & \multicolumn{4}{|c|}{ Group 5} & & & & \\
\hline & \multicolumn{2}{|c|}{ MF7 } & \multicolumn{2}{|c|}{ MF23 } & \multicolumn{2}{|c|}{ MF58 } & \multicolumn{2}{|c|}{ MF63 $^{\mathrm{T}}$} & \multicolumn{2}{|c|}{ MF441 } & \multicolumn{2}{|c|}{ Td17 } & \multicolumn{2}{|c|}{$\mathbf{T d 2 1}^{\mathrm{T}}$} & & & & \\
\hline & $\mathbf{O}_{2}$ & $\mathrm{NO}_{3}^{-}$ & $\mathbf{O}_{2}$ & $\mathrm{NO}_{3}^{-}$ & $\mathbf{O}_{2}$ & $\mathrm{NO}_{3}^{-}$ & $\mathbf{O}_{2}$ & $\mathrm{NO}_{3}^{-}$ & $\mathrm{O}_{2}$ & $\mathrm{NO}_{3}^{-}$ & $\mathrm{O}_{2}$ & $\mathrm{NO}_{3}^{-}$ & $\mathbf{O}_{2}$ & $\mathrm{NO}_{3}^{-}$ & & & & \\
\hline Caproate & - & - & - & - & - & - & - & - & - & - & - & - & + & + & & & & \\
\hline D-Fructose & - & - & - & - & + & - & + & + & + & + & - & - & - & + & & & & \\
\hline Fumarate & - & - & - & - & - & - & - & + & + & + & + & + & + & + & & & & \\
\hline D-Glucose & + & + & - & - & - & - & + & \pm & + & \pm & - & - & - & - & & & & \\
\hline 3-Hydroxybenzoate & - & - & - & - & - & - & - & - & - & - & - & - & - & - & & & & \\
\hline 4-Hydroxyphenylacetate & - & - & - & - & - & - & - & - & - & - & - & - & - & - & & & & \\
\hline Phenol & - & - & - & - & + & + & - & - & ND & + & ND & + & ND & + & & & & \\
\hline Phenylacetate & - & - & - & - & - & - & - & + & - & + & + & + & + & + & & & & \\
\hline Propionate & - & - & - & - & - & - & - & - & - & - & - & - & + & - & & & & \\
\hline Toluene & + & + & - & - & + & + & - & + & - & + & + & + & + & + & & & & \\
\hline Valerate & - & - & - & - & - & - & - & - & - & + & - & + & + & - & & & & \\
\hline Lactose & + & + & + & + & + & + & + & + & + & + & + & - & - & + & & & & \\
\hline Phenylalanine & - & - & + & + & + & + & - & - & + & + & \pm & \pm & \pm & + & & & & \\
\hline
\end{tabular}

on acetate, adipate, arginine, L-arabinose, aspartate, benzoate, D-galactose, lactate, maltose, mannitol, proline, pyruvate, D-ribose, succinate, sucrose or D-xylose. Under denitrifying conditions, 4-hydroxybenzoate was used by all strains. None of them grew on acetamide, histamine, 2-hydroxybenzoate, starch or tartrate under either condition. Only strain MF62 utilized phthalate under denitrifying conditions. Butyrate and toluene were used by all strains except strain MF23, under denitrifying conditions. The variations in the utilization of substrates by strains of different groups are given in Table 4. Although it is true that strains of groups 1,2 and 5 can grow at the expense of a larger number of different substrates than the strains of groups 3 and 4 , from the available data, it is impossible to define characteristic nutritional phenotypes.

\section{Conclusions}

The strains in this study can be classified into three species and five separate taxa on the basis of the combination of all the analyses performed. Group 1 consists of strains Td1, Td2, MF66 and Tol- $4^{\mathrm{T}}$, the latter being the type strain of the species $A$. tolulyticus (Zhou et al., 1995). Thus, group 1 should conserve this species name. Group 2 includes isolates from Northern Michigan and it is closely related to group 1 on the basis of DNA similarity, which is shown graphically in 
the three-dimensional representation, in the protein banding pattern and DNA fragmentations, and in the phylogenetic tree of $16 \mathrm{~S}$ rRNA. The results of the fatty acid analyses and the nutritional screening do not further support the results of the above-mentioned approaches. Thus, group 2 could be considered to be a genomovar of $A$. tolulyticus on the basis of criteria defined by Ursing et al. (1995).

Groups 3 (strains MF7 and MF23) and 4 (strains MF58, MF63 ${ }^{\mathrm{T}}$ and MF441), which consist of isolates from Moffett Field, have 47-55\% DNA similarity with each other and low similarities with other groups. They form a tight group, as suggested by the fatty acid composition, and show very similar protein profiles and DNA fragment patterns (except for strain MF7) and less nutritional versatility than the other groups. In addition, strains MF7 and MF $63^{\mathrm{T}}$ from group 3 and group 4, respectively, form a cluster on the basis of $16 \mathrm{~S}$ rRNA gene sequence analysis. Thus, groups 3 and 4 should be considered as a distinct species and a genomovar, respectively, of the genus Azoarcus.

Group 5 (strains $\operatorname{Td} 17$ and $\operatorname{Td} 21^{\mathrm{T}}$ ), previously considered to be $A$. tolulyticus (Zhou et al., 1995), has low DNA similarity and different protein and DNA fragment patterns to group 1 (A.tolulyticus) and is well separated from group 1 in the phylogenetic tree and dendrogram of fatty acids analysis. Thus, this group should be considered as a new species of the genus Azoarcus.

The remaining strains (Td3, Td19, MF62, MF107 and MF118) do not cluster with any of the main groups 1 through 5. Each of them could represent an individual species. Strains MF107 and MF118 have 50\% DNA similarity with group 1 and $40 \%$ DNA similarity with group 3 as well as similar protein patterns to groups 1 and 3. Thus, they may be included in the cluster of the genus Azoarcus as individual new species related to either group 1 or group 3. Strains Td3 and Td19, previously reported as the species $A$. tolulyticus, have about $30 \%$ DNA similarity with groups 1 and 2 , which constitute the species $A$. tolulyticus, and low DNA similarity with any of the other groups. 16S rRNA gene sequence analysis of these strains shows a difference with the species $A$. tolulyticus, but they still remain in the cluster of the genus Azoarcus. This observation correlates with the analysis of fatty acid profiles. Thus, these separate strains might be considered as individual species in the genus Azoarcus and named in the future. Strain MF62 has no relatedness with any of the strains within the genus Azoarcus.

In addition to the experiments reported above, $A$. evansii strain $\mathrm{KB} 740^{\mathrm{T}}$ was used as a reference strain in the DNA-DNA hybridization experiments. These were done to test its relationship to strains MF118, Td3 and A. tolulyticus (strains Td1 and MF66). Strains KB $740^{\mathrm{T}}$ and MF118 are very similar in terms of cellular fatty acid composition, but the protein profiles are different and the DNA similarity is low (31\%). On the other hand, strain Td3 has high 16S rRNA sequence similarity with strain KB $740^{\mathrm{T}}$ (Fig. 3; Table 3 ) and the DNA similarity value is relatively high $(52 \%)$, but both the protein profiles and the fatty acid composition are quite different. A similar value for DNA similarity $(57 \%)$ has been obtained between KB $740^{\mathrm{T}}$ and $A$. tolulyticus (strains Td1 and MF66), although there are clear differences both in protein profiles and fatty acid composition. These facts suggest the possibility that $A$. evansii may actually be a sibling and not a genomovar of both strain $\mathrm{Td} 3$ and $A$. tolulyticus.

It is clear that the various Azoarcus species groups show considerable internal diversity and a wide geographical and ecological distribution (Table 1). They were isolated from soils as well as from freshwater and marine sediments in Michigan, Washington, California and Brazil. For the moment, the identification of additional strains isolated after similar enrichment procedures may require the application of molecular methods, particularly DNA-DNA reassociation studies, supplemented if possible with whole-cell protein and DNA restriction fragmentation studies, using as standards preparations obtained from members of the taxa described here.

\section{New strains assigned to the species Azoarcus tolulyticus}

One of the main physiological characteristics of the species $A$. tolulyticus is its capacity for toluene degradation under denitrifying conditions. The description of species $A$. tolulyticus was reported previously (Zhou et al., 1995). The cells of strain MF66 of Azoarcus tolulyticus are short motile rods with monopolar flagellation. This strain can grow under aerobic and denitrifying conditions with acetate, benzoate, butyrate, D-fructose, fumarate, D-glucose, phenol, pyruvate, succinate, toluene, D-xylose, L-arabinose, Dribose, D-galactose, sucrose, lactose, maltose, adipate, lactate, mannitol, aspartate, proline, phenylalanine or arginine. Under denitrifying conditions, 4-hydroxybenzoate is used as a growth substrate. The cells are oxidase-positive and catalase-negative and grow on brain-heart infusion plates, but do not grow on nutrient and trypticase soy agar plates. The predominant fatty acids are $16: 0$ and $16: 1 \omega 7 c$, similar to the other members of the species $A$. tolulyticus. Therefore, it belongs to the species $A$. tolulyticus based on $16 \mathrm{~S}$ rRNA gene sequence analysis, DNA-DNA hybridization, similar patterns of whole-cell proteins and genomic DNA analysis.

The isolates from Northern Michigan (strains 2a1, 3a1, 7a1, BL2 and BL11) are short motile rods with monopolar flagellation They can grow on acetate, benzoate, butyrate, D-fructose, fumarate, D-glucose, pyruvate, succinate, D-xylose, L-arabinose, D-ribose, D-galactose, sucrose, lactose, maltose, adipate, lactate, mannitol, aspartate, proline or arginine under aerobic and denitrifying conditions and use 4-hydroxybenzoate and toluene for growth under denitrifying 
conditions. They grow on brain-heart infusion, nutrient and trypticase soy agar plates and give positive reactions in the catalase and oxidase tests. The different colony morphology of these strains on half-strength trypticase soy agar plus nitrate at $30^{\circ} \mathrm{C}$ for $48 \mathrm{~h}$ has been reported (Chee-Sanford et al., 1996). The predominant fatty acids are 16:0 and 16:1 $\omega 7 c$. Wholecell protein and genomic DNA fragmentation analyses show identical patterns to the other members of $A$. tolulyticus and 16S rRNA sequence analysis of one strain (BL11) shows a close relationship with the members of A. tolulyticus. Thus, we conclude that they belong to the species $A$. tolulyticus, although the DNA homologies between these isolates and the strains of $A$. tolulyticus are about $55 \%$; therefore, they constitute a genomovar of this species.

\section{Description of Azoarcus toluvorans sp. nov.}

Azoarcus toluvorans (to.lu.vo'rans. N.L. n. Fr. Sp. tolu balsam from Santiago de Tolu, toluene; L. part. adj. vorans devouring; M.L. part. adj. toluvorans toluenedevouring).

The species is represented in our collection by strains $\mathrm{Td} 17$ and $\mathrm{Td} 21^{\mathrm{T}}$, which were previously classified as $A$. tolulyticus. The new designation is justified on the basis of 16S rRNA gene sequence analysis, DNA-DNA hybridization results and characteristic patterns of whole-cell proteins. Both strains grow on brain-heart infusion, nutrient and trypticase soy agar. They can use as sole sources of carbon and energy acetate, benzoate, butyrate, fumarate, phenylacetate, pyruvate, succinate, toluene, D-xylose, L-arabinose, D-ribose, Dgalactose, sucrose, maltose, adipate, lactate, mannitol, aspartate, proline, phenylalanine or arginine under aerobic and denitrifying conditions. Both strains can use benzene or ethylbenzene under aerobic conditions only and 4-hydroxybenzoate or phenol under denitrifying conditions. The $\mathrm{G}+\mathrm{C}$ content of the DNA is about $67.8 \mathrm{~mol} \%$. Other characteristics are the same as described previously (Fries et al., 1994). The type strain is $\operatorname{Td} 21^{\mathrm{T}}\left(=\right.$ ATCC $\left.700604^{\mathrm{T}}\right)$.

\section{Description of Azoarcus toluclasticus sp. nov.}

Azoarcus toluclasticus (to.lu.clas'ti.cus. N.L. n. Fr. Sp. tolu balsam from Santiago de Tolu, toluene; Gr. adj. clasticus breaking; M.L. adj. toluclasticus toluenebreaking).

The members of groups 3 and 4 (strains MF7, MF23, MF58, MF63 ${ }^{\mathrm{T}}$ and MF441) among the isolates from Moffett Field are assigned to this new species. The strains are short motile rods with polar monotrichous flagellation and can grow on acetate, benzoate, pyruvate, succinate, D-xylose, L-arabinose, D-ribose, Dgalactose, sucrose, lactose, maltose, adipate, lactate, mannitol, aspartate, proline or arginine under aerobic and denitrifying conditions. All strains except strain MF23 can use toluene as a growth substrate and strains MF58 and MF63 ${ }^{\mathbf{T}}$ can also grow on phenol under denitrifying conditions. The strains grow on brain-heart infusion, nutrient and trypticase soy agar, except for strain MF63 ${ }^{\mathrm{T}}$, which does not grow on nutrient agar. The oxidase test is positive and the catalase test is negative. The predominant fatty acids are $16: 0$ and $16: 1 \omega 7 c$. The $\mathrm{G}+\mathrm{C}$ content of the DNA is about $67.3 \mathrm{~mol} \%$. Phylogenetic analyses of $16 \mathrm{~S}$ rRNA and DNA-DNA hybridization show the relatedness of strains to the genus Azoarcus and the differences from the species $A$. tolulyticus. Thus, strains MF58, MF63 ${ }^{\mathrm{T}}$ and MF441 are considered to be members of a new species, Azoarcus toluclasticus, and strains MF7 and MF23 represent a genomovar of this species. The type strain is $\mathrm{MF}^{\mathrm{T}}{ }^{\mathrm{T}}\left(=\mathrm{ATCC} 700605^{\mathrm{T}}\right)$.

\section{ACKNOWLEDGEMENTS}

We gratefully acknowledge Dr Lily Y. Young for providing laboratory facilities. The Rutgers work was supported in part by grants from DARPA, EPA and ONR, and the Michigan work by NIEHS, Grant no. ES-04911.

\section{REFERENCES}

Altenschmidt, U. \& Fuchs, G. (1991). Anaerobic degradation of toluene in denitrifying Pseudomonas sp.: indication for toluene methylhydroxylation and benzyl-CoA as central aromatic intermediate. Arch Microbiol 156, 152-158.

Anders, H., Kaetzke, A., Kămpfer, P., Ludwig, W. \& Fuchs, G. (1995). Taxonomic position of aromatic-degrading denitrifying Pseudomonad strains K 172 and KB 740 and their description as new members of the genera Thauera, as Thauera aromatica sp. nov., and Azoarcus, as Azoarcus evansii sp. nov., respectively, members of the beta subclass of the Proteobacteria. Int $J$ Syst Bacteriol 45, 327-333.

Biegert, T. \& Fuchs, G. (1996). Anaerobic oxidation of toluene (analogues) to benzoate (analogues) by whole cells and by cell extracts of a denitrifying Thauera sp. Arch Microbiol 163, $407-417$.

Bradford, M. M. (1976). A rapid and sensitive method for the quantitation of microgram quantities of protein utilizing the principle of protein-dye binding. Anal Biochem 72, 248-254.

Chee-Sanford, J. C., Frost, J. W., Fries, M. R., Zhou, J. \& Tiedje, J. M. (1996). Evidence for acetyl coenzyme A and cinnamoyl coenzyme $\mathrm{A}$ in the anaerobic toluene mineralization pathway in Azoarcus tolulyticus Tol-4. Appl Environ Microbiol 62, 964-973.

Devereux, J., Haeberli, P. \& Smithies, O. (1984). A comprehensive set of sequence analysis programs for the VAX. Nucleic Acids Res 12, 387-395.

Evans, P. J., Mang, D. T., Kim, K. S. \& Young, L. Y. (1991). Anaerobic degradation of toluene by a denitrifying bacterium. Appl Environ Microbiol 57, 1139-1145.

Felsenstein, J. (1985). Confidence limits on phylogenies: an approach using the bootstrap. Evolution 39, 783-791.

Felsenstein, J. (1989). PHYLIP - Phylogeny inference package (version 3.2). Cladistics 5, 164-166.

Frazer, A. C., Coschigano, P. W. \& Young, L. Y. (1995). Toluene metabolism under anaerobic conditions: a review. Anaerobe 1, 293-303.

Fries, M. R., Zhou, J., Chee-Sanford, J. C. \& Tiedje, J. M. (1994). Isolation, characterization, and distribution of denitrifying 
toluene degraders from a variety of habitats. Appl Environ Microbiol 60, 2802-2810.

Fries, M. R., Forney, L. J. \& Tiedje, J. M. (1997a). Phenol- and toluene-degrading microbial populations from an aquifer in which successful trichloroethene cometabolism occurred. Appl Environ Microbiol 63, 1523-1530.

Fries, M. R., Hopkins, G. D., McCarty, P. L., Forney, L. J. \& Tiedje, J. M. (1997b). Microbial succession during a field evaluation of phenol and toluene as the primary substrates for trichloroethene cometabolism. Appl Environ Microbiol 63, 1515-1522.

Goodfellow, M. \& O'Donnell, A. G. (1993). Roots of bacterial systematics. In Handbook of New Bacterial Systematics, pp. 3-56. Edited by M. Goodfellow \& A. G. O'Donnell. San Diego, CA: Academic Press.

Gorny, N., Wahl, G., Brune, A. \& Schink, B. (1992). A strictly anaerobic nitrate-reducing bacterium growing with resorcinol and other aromatic compounds. Arch Microbiol 158, 48-53.

Harder, J. (1997). Anaerobic degradation of cyclohexane-1,2diol by a new Azoarcus species. Arch Microbiol 168, 199-204.

Heider, J. \& Fuchs, G. (1997). Anaerobic metabolism of aromatic compounds. Eur J Biochem 243, 577-596.

Hildebrand, D. C., Schroth, M. N. \& Huisman, O. C. (1982). The DNA homology matrix and non-random variation concepts as the basis for the taxonomic treatment of plant pathogenic and other bacteria. Annu Rev Phytopathol 20, 235-256.

Hildebrand, D. C., Huisman, O. C. \& Schroth, M. N. (1984). Use of DNA hybridization values to construct three-dimensional models of fluorescent pseudomonad relationships. Can $J$ Microbiol 30, 306-315.

Hood, D. W., Dow, C. S. \& Green, P. N. (1988). Electrophoretic comparison of total soluble proteins in the pink-pigmented facultative methylotrophs. J Gen Microbiol 134, 2375-2383.

Hurek, T., Wagner, B. \& Reinhold-Hurek, B. (1997). Identification of $\mathrm{N}_{2}$-fixing plant- and fungus-associated Azoarcus species by PCR-based genomic fingerprints. Appl Environ Microbiol 63, 4331-4339.

Jackman, P. J. H. (1984). Bacterial taxonomy based on electrophoretic whole-cell protein patterns. In Chemical Methods in Bacterial Systematics, pp. 115-130. Edited by M. Goodfellow \& D. E. Minnikin. Orlando: Academic Press.

Kimura, M. (1980). A simple method for estimating evolutionary rate of base substitutions through comparative studies of nucleotide sequences. $J$ Mol Evol 16, 111-120.

Leifson, E. (1951). Staining, shape, and arrangement of bacterial flagella. J Bacteriol 62, 377-389.

Mesbah, M., Premachandran, U. \& Whitman, W. B. (1989). Precise measurement of the $\mathrm{G}+\mathrm{C}$ content of deoxyribonucleic acid by high-performance liquid chromatography. Int $J$ Syst Bacteriol 39, 159-167.

Migaud, M. E., Chee-Sanford, J. C., Tiedje, J. M. \& Frost, J. W. (1996). Benzylfumaric, benzylmaleic, and $Z$ - and $E$-phenylitaconic acids: synthesis, characterization, and correlation with a metabolite generated by Azoarcus tolulyticus Tol-4 during anaerobic toluene degradation. Appl Environ Microbiol 62, 974-978.
Rabus, R. \& Widdel, F. (1996). Anaerobic degradation of ethylbenzene and other aromatic hydrocarbons by new denitrifying bacteria. Arch Microbiol 163, 96-103.

Rainey, P. B., Thompson, I. P. \& Palleroni, N. J. (1994). Genome and fatty acid analysis of Pseudomonas stutzeri. Int $J$ Syst Bacteriol 44, 54-61.

Reinhold-Hurek, B., Hurek, T., Gillis, M., Hoste, B., Vancanneyt, M., Kersters, K. \& De Ley, J. (1993). Azoarcus gen. nov., nitrogenfixing Proteobacteria associated with roots of Kallar Grass (Leptochloa fusca L. Kunth), and description of two species, Azoarcus indigens sp. nov. and Azoarcus communis sp. nov. Int $J$ Syst Bacteriol 43, 574-584.

Rhee, S., Lee, G. H., Yoon, J., Bae, H., Park, Y. \& Lee, S. (1997). Anaerobic and aerobic degradation of pyridine by a newly isolated denitrifying bacterium. Appl Environ Microbiol 63, $2578-2585$

Saitou, N. \& Nei, M. (1987). The neighbor-joining method: a new method for reconstructing phylogenetic trees. Mol Biol Evol 4, 406-425.

van Schie, P. M. \& Young, L. Y. (1998). Isolation and characterization of phenol-degrading denitrifying bacteria. Appl Environ Microbiol 64, 2432-2438.

Seyfried, B., Glod, G., Schocher, R., Tschech, A. \& Zeyer, J. (1994). Initial reactions in the anaerobic oxidation of toluene and $m$ xylene by denitrifying bacteria. Appl Environ Microbiol 60, $4047-4052$.

Smibert, R. M. \& Krieg, N. R. (1994). Phenotypic characterization. In Methods for General and Molecular Bacteriology, pp. 607-654. Edited by P. Gerhardt, R. G. E. Murray, W. A. Wood \& N. R. Krieg. Washington, DC: American Society for Microbiology.

Song, B., Young, L. Y. \& Palleroni, N. J. (1998). Identification of denitrifier strain $\mathrm{T} 1$ as Thauera aromatica and proposal for emendation of the genus Thauera definition. Int J Syst Bacteriol 48, 889-894.

Springer, N., Ludwig, W., Philipp, B. \& Schink, B. (1998). Azoarcus anaerobius sp. nov., a resorcinol-degrading, strictly anaerobic, denitrifying bacterium. Int $J$ Syst Bacteriol 48, 953-956.

Stackebrandt, E. \& Goebel, B. M. (1994). Taxonomic note: a place for DNA-DNA reassociation and $16 \mathrm{~S}$ rRNA sequence analysis in the present species definition in bacteriology. Int $J$ Syst Bacteriol 44, 846-849.

Tschech, A. \& Fuchs, G. (1987). Anaerobic degradation of phenol by pure cultures of newly isolated denitrifying pseudomonads. Arch Microbiol 148, 213-217.

Ursing, J. B., Rossello-Mora, R. A., Garcia-Vales, E. \& Lalucat, J. (1995). Taxonomic note: a pragmatic approach to the nomenclature of phenotypically similar genomic groups. Int J Syst Bacteriol 45, 604

Weisburg, W. W., Barns, S. M., Pelletier, D. A. \& Lane, D. J. (1991) $16 \mathrm{~S}$ ribosomal DNA amplification for phylogenetic study. $J$ Bacteriol 173, 697-703.

Zhou, J., Fries, M. R., Chee-Sanford, J. C. \& Tiedje, J. M. (1995). Phylogenetic analyses of a new group of denitrifiers capable of anaerobic growth on toluene and description of Azoarcus tolulyticus sp. nov. Int $J$ Syst Bacteriol 45, 500-506. 